\title{
Antioxidant properties of essential oils from Mentha species evidenced by electrochemical methods
}

\author{
GONÇALVES, R.S. ${ }^{1 *}$; BATTISTIN, A. ${ }^{2}$; PAULETTI, G. ${ }^{3}$; ROTA, L. ${ }^{3}$; SERAFINI, L.A. ${ }^{3}$ \\ ${ }^{1}$ Universidade Federal do Rio Grande do Sul, Caixa Postal 15049, CEP: 91501-970, Porto Alegre-Brasil \\ *reinaldo@iq.ufrgs.br ${ }^{2}$ Fundação Estadual de Pesquisa Agropecuária (FEPAGRO), Av. Gonçalves Dias, 570, B. \\ Menino Deus, CEP:90130-060, PortoAlegre-Brasil alice-battistin@fepagro.rs.gov.br ${ }^{3}$ Instituto de Biotecnologia, \\ Universidade de Caxias do Sul - Av. Francisco Getúlio Vargas, 1130, B. Petrópolis, CEP: 95070-560, Caxias do \\ Sul-Brasil gabriel.pauletti@gmail.com
}

\begin{abstract}
RESUMO: Propriedades antioxidantes de óleos essenciais de espécies de Mentha evidenciadas por métodos eletroquímicos. Neste trabalho foram determinadas as capacidades antioxidantes dos óleos extraídos de Mentha spicata L., Mentha x gentilis L., Mentha crispa L., Mentha piperita L. e Mentha x piperita L. pelo método da voltametria de pulso diferencial. Esta determinação baseou-se na diminuição do valor limite da corrente de eletrorredução do oxigênio, a partir do qual foi possível calcular o valor da capacidade antioxidante $(K)$ destas espécies. A espécie que apresentou o maior valor de K foi a M. $x$ gentilis L. Os dados experimentais obtidos por voltametria cíclica indicaram a interação entre a superfície do eletrodo de platina e os componentes ativos presentes nos óleos essenciais. Uma metodologia simples para a determinação da habilidade quelante dos componentes ativos dos óleos essenciais em relação ao Fe (II) também é apresentada.
\end{abstract}

Palavras-chave: capacidade antioxidante, óleo essencial, Mentha, habilidade quelante do Fe (II)

\begin{abstract}
The antioxidant capacity of essential oils of Mentha spicata L., Mentha x gentilis L., Mentha crispa L., Mentha piperita L. and Mentha x piperita L. was determined by using differential pulse voltammetry. This assay was based on the reduction in the limiting current value of the oxygen electroreduction, which was used to calculate the antioxidant capacity $(K)$ of these species. The species $M$. $x$ gentilis $\mathrm{L}$. had the highest $\mathrm{K}$ value. Cyclic voltammetry experiments confirmed the interaction between the electrode surface and the active compounds present in the essential oils. A simple electrochemical method for determining the ability of active compounds to chelate $\mathrm{Fe}(\mathrm{II})$ is proposed.
\end{abstract}

Key words: antioxidant capacity, essential oils, Mentha, Fe (II) chelating ability

\section{INTRODUCTION}

Phenolic and volatile compounds naturally occur in plants, including herb species, and show antioxidant properties. Of these, some mint species have received attention as preventive medicines since they have beneficial health effects, such as antioxidant and antibacterial activity (Dukic et al., 2003; Gulluce et al., 2007).

The genus Mentha (Lamiaceae) comprises approximately 25-30 species that may be found in South America. Some of them produce volatile oils that are of great economic importance in the pharmaceutical and food industries (Dorman et al.,
2003). Phenolic acids, flavonoids, terpenoids and volatile compounds have been identified as the major compounds found in different extracts of mint (Choudhury et al., 2006). The role of phenolic acids, their derivatives and flavonoids involves the ability to scavenge radicals through electron transfer with reactive oxygen species (ROS). The antioxidant capacity of Mentha piperita L. extracts during the oxidation of sunflower oil at $100^{\circ} \mathrm{C}$ has been observed by comparing peroxide accumulation in the absence and presence of extracts (Marinova \& Yanishlieva, 1997). The radical scavenging capacity (RSC) of

Recebido para publicação em 20/08/2008

Aceito para publicação em 30/06/2009 
Menha essential oils has been evaluated by measuring the scavenging activity based on 2,2-diphenyl-1picrylhydrazyl (DPPH) and $\beta$-carotene/linoleic methods and it was reported that Mentha longifolia $L$. (Dukic et al., 2003; Gulluce et al., 2007), M. piperita L. (Dukic et al., 2003; Yadegarinia, et al., 2006; Dorman et al., 2003; Capecka et al., 2005; Politeo et al., 2006), Mentha aquatica L. ( Dorman et al., 2003), Mentha spicata L. (Dorman et al., 2003; Choudhury et al., 2006; Arabshahi et al., 2007; Kanatt et al., 2007), Mentha arvensis (Chanwitheesuk et al., 2005), Mentha suaveolens (Ferreira et al., 2006) and Mentha pulegium (Mata et al., 2007) present antioxidant capacity. The antioxidant capacity could be determined by using pulse differential voltammetry, recording the current of the electrochemical oxygen reduction at the electrode surface. In the absence of Mentha extracts the charge transfer processes proceed through several stages with formation of the superoxide anion-radical of oxygen:

$$
\begin{aligned}
& \mathrm{O}_{2}+\mathrm{e}^{-} \rightleftarrows\left[\mathrm{O}_{2}^{\circ}\right]^{-} \\
& {\left[\mathrm{O}_{2}^{\circ}\right]^{-}+\mathrm{H}^{+} \rightleftarrows \mathrm{HO}_{2}} \\
& \mathrm{HO}_{2}+\mathrm{H}^{+}+\mathrm{e}^{-} \rightleftarrows \mathrm{H}_{2} \mathrm{O}_{2} \\
& \mathrm{H}_{2} \mathrm{O}_{2}+2 \mathrm{H}^{+}+2 \mathrm{e}^{-} \rightleftarrows 2 \mathrm{H}_{2} \mathrm{O}
\end{aligned}
$$

Antioxidants reacting with the superoxide $\left[\mathrm{O}_{2}{ }^{\circ}\right]$ decrease its concentration at the electrode under otherwise unchanging conditions. At the same time, the electrochemical oxygen reduction current decreases and, therefore, it can be used as a value comparable with the antioxidant capacity in the solution under analysis (Korotkova et al., 2002). Thus, the screening of antioxidant power was performed by using differential pulse voltammetry (DPV). Some experiments using cyclic voltammetry were also performed. The presence of reduced metallic ions has been reported to result in a pro-oxidant effect that accelerates the peroxidation process (Yamauchi et al., 1988). The ability of plant extracts to chelate iron
(II) is described in literature as a way to evaluate the inhibition of this activity, including Mentha species (Kosar et al., 2005). However, the used analytical method is based on the spectrophotometric analysis of aqueous/alcoholic solutions of $\mathrm{FeCl}_{2}$ in the presence of ferrozine as the initiator (Kosar et al., 2005). In this paper we report the results of a study on antioxidant activities and iron (II) chelation ability of natural antioxidants from Mentha species extracts, based on electrochemical methods.

\section{MATERIAL AND METHOD}

\section{Plants}

In this paper five species of the family Lamiaceae (see Table 1), cultivated in Rio Grande do Sul State (Brazil), were studied.

\section{Distilled Essential Oil}

Essential oils were distilled from shoots of the plants in a steam distillation apparatus for $90 \mathrm{~min}$. The amount of dried plant material used was $3 \mathrm{~kg}$. Steam and essential oils were condensed and collected in a Florentine flask. The oils were dried over sodium sulfate, stored in clean brown glass bottles and kept in a controlled-temperature chamber at $20^{\circ} \mathrm{C}$ until analysis.

\section{Chemical Identification}

Gas chromatography (GC) analysis was performed on a Hewlett Packard 6890 Series chromatograph equipped with an HP-Chemstation data processor, fitted with an HP-Innowax bonded phase capillary column ( $30 \mathrm{~m} \times 0.32 \mathrm{~mm}$ i.d., 0.50 $\mathrm{mm}$ film thickness, Hewlett Packard, Palo Alto, USA); column temperature $40^{\circ} \mathrm{C}(8 \mathrm{~min})$ to $180^{\circ} \mathrm{C}$ at $3^{\circ} \mathrm{C}$ $\mathrm{min}^{-1}, 180-230^{\circ} \mathrm{C}$ at $20^{\circ} \mathrm{C} \mathrm{min}^{-1}, 230^{\circ} \mathrm{C}$ (20 min); injector temperature $250^{\circ} \mathrm{C}$; detector temperature $250^{\circ} \mathrm{C}$; split ratio 1:50; carrier gas $\mathrm{H}_{2}$ ( $34 \mathrm{KPa}$ ); volume injected $1 \mathrm{~mL}$ diluted in hexane (1:10). The GC/MS

TABLE 1. Species, voucher number, cultivation sites and collection date of five species of Mentha L.

\begin{tabular}{llll}
\hline \multicolumn{1}{c}{ Species } & Voucher & \multicolumn{1}{c}{ Cultivation site } & $\begin{array}{c}\text { Collection } \\
\text { date }\end{array}$ \\
\hline Mentha spicata L. & HUCS-26629 & Caxias do Sul/FEPAGRO/RS/BR & $14 / 02 / 2006$ \\
Mentha x gentilis L. & HUCS-26627 & Caxias do Sul/UCS/IB/RS/BR & $16 / 03 / 2005$ \\
Mentha crispa L. & BLA - 17254 & Eldorado do Sul/FEPAGRO/RS/BR & $26 / 01 / 2006$ \\
Mentha piperita L. & BLA - 17255 & Eldorado do Sul/FEPAGRO/RS/BR & $26 / 01 / 2006$ \\
Mentha x piperita L & HUCS-27666 & Caxias do Sul/FEPAGRO/RS/BR & $14 / 02 / 2006$ \\
\hline
\end{tabular}

HUCS - Herbário Universidade Caxias do Sul. BLA - Brazilian Laboratory of Agrostology. FEPAGRO - Fundação Estadual de Pesquisa Agropecuária UCS - Universidade de Caxias do Sul IB - Instituto de Biologia 
analysis was performed on an HP $6890 \mathrm{GC}$ using a Hewlett Packard 6890/MSD5973 mass selective detector, equipped with HP Chemstation software and Wiley 275 spectral database. An HP-Innowax fused silica capillary column $(30 \mathrm{~m} \times 0.25 \mathrm{~mm}), 0.25 \mathrm{~mm}$ film thickness (Hewlett Packard, Palo Alto, USA) was used. The temperature program was the same used in the GC analysis: interface $280^{\circ} \mathrm{C}$; split ratio 1:100; carrier gas $\mathrm{He}(56 \mathrm{KPa})$; flow rate: $1.0 \mathrm{~mL} \mathrm{~min}^{-1}$; ionization energy $70 \mathrm{eV}$; mass range 40-350; and volume injected $0.4 \mathrm{~mL}$ diluted in hexane $(1: 10)$. Identification of the individual compounds was based on comparison of their $\mathrm{GC}$ retention indices (RI) on polar columns and comparison with mass spectra of compounds by $\mathrm{GC} / \mathrm{MS}$.

\section{Determination of iron (II) chelating effect}

The electrochemical system, with platinum wire and silver/silver chloride as working and reference electrodes, respectively, was mounted inside a glass electrochemical cell containing $30 \mathrm{~mL}$ of aqueous ethanolic (1:1) $(\mathrm{v} / \mathrm{v})$ solution with dissolved $\mathrm{FeSO}_{4} 5.0 \times 10^{-4} \mathrm{~mol} \mathrm{~L}^{-1}$ and sulfuric acid $0.25 \mathrm{~mol} \mathrm{~L}^{-1}$. The solution was kept under constant stirring and the open-circuit potential was read directly, after the stabilization of the potential $x$ time had been reached. A previously weighed drop of Mentha extract was then added directly into the ethanolic solutions and the potential values recorded.

The procedure was based on the Nernst equation. The potential value is dependent on the $\mathrm{Fe}(\mathrm{II}) / \mathrm{Fe}$ (III) equilibrium on the platinum surface according to the equation:

$$
\mathrm{E}=\mathrm{E}^{\mathrm{O}^{\prime}}+\frac{\mathrm{RT}}{\mathrm{F}} \ln \left(\frac{\mathrm{a}_{\mathrm{Fe}(\mathrm{III})}}{\mathrm{a}_{\mathrm{Fe}(\mathrm{II})}}\right)
$$

where $E$ is the open-circuit potential at time (t) and $\mathrm{E}^{\circ}$ is the open-circuit potential for the unitary activity of the species.

The chelating ability was evaluated through the potential displacement, comparing the potential value in the absence and presence of Mentha extracts. The open-circuit potential should be shifted to a more positive potential value if the $\mathrm{Fe}(\mathrm{II})$ ion is being inhibited by the reaction:

$$
\mathrm{Fe}(\mathrm{II})+\mathrm{L} \rightarrow[\mathrm{Fe}(\mathrm{L})]^{2+}
$$

where $L$ is the active chelating compound present in Mentha extract.

By assuming that this is a first-order reaction regarding $\mathrm{Fe}$ (II) concentration, a simple plot based on $\ln \left(\frac{[\mathrm{Fe}(\mathrm{II})]}{[\mathrm{Fe}(\mathrm{II})]_{\mathrm{o}}}\right)$ should vary linearly against time.

Considering Nernst equation for two different

$$
\begin{aligned}
& t=0 \quad E^{\prime}=E^{o^{\prime}}+\frac{R T}{F} \ln \left(\frac{[\mathrm{Fe}(\mathrm{III})]}{[\mathrm{Fe}(\mathrm{II})]_{\mathrm{o}}}\right) \text { and } \\
& t \neq 0 \quad E=E^{\mathrm{o}^{\prime}}+\frac{\mathrm{RT}}{\mathrm{F}} \ln \left(\frac{[\mathrm{Fe}(\mathrm{III})]}{[\mathrm{Fe}(\mathrm{II})]}\right)
\end{aligned}
$$

the difference is determined by

$$
\begin{gathered}
E^{\prime}-E=k \ln \left(\frac{[\mathrm{Fe}(\mathrm{II})]}{[\mathrm{Fe}(\mathrm{II})]_{\mathrm{o}}}\right) ; \\
\text { or } \Delta E=k \ln \left(\frac{[\mathrm{Fe}(\mathrm{II})]}{[\mathrm{Fe}(\mathrm{II})]_{\mathrm{o}}}\right) \text { for } \mathrm{t} \neq 0
\end{gathered}
$$

Thus, the linearity of the plot DE vs. time after the addition of Mentha extracts may be used to confirm the chelating effect as well as to calculate the rate of this chelating reaction based on the slope coefficient of the straight line.

\section{Antioxidant capacity}

For these experiments a three-electrode glass electrochemical cell, with silver/silver chloride $(\mathrm{KCl}$ saturated) and platinum wire as the reference and counter electrodes, respectively, was used. The working electrode was a disk of pure platinum $(A=$ $\left.0.196 \mathrm{~cm}^{2}\right)$. Prior to each experiment the working electrode was polished with no. 2000 sandpaper and rinsed with distilled water. Aqueous solutions (1:1) water:ethanol $(\mathrm{v} / \mathrm{v})$ containing $0.10 \mathrm{~mol} \mathrm{~L}^{-1}$ tetraethylammonium chloride as the supporting electrolyte were used. A simple digital MINIPA multimeter, model ET1001, was used for the potentiometric determinations and an EcoChimie potentiostat, model Autolab PGSTAT30, for the cyclic voltammetry and differential pulse voltammetry. All reagents used in this study were of analytical grade and had no further purification. Ethanol was purchased from Nuclear and tetraethylammonium chloride from Acrós. To obtain good reproducibility all experiments were repeated at least three times.

\section{RESULT AND DISCUSSION}

Chemical composition of the essential oils The chemical composition of the studied species is shown in Table 2.

As presented in the table, the chemical compositions of these Menthaspecies are quite varied.

\section{Iron (II) chelating determination}

Figure 1 represents the potential $x$ time values obtained for $M$. $x$ gentilis $\mathrm{L}$. using the previously described procedure. 
TABLE 2. Chemical compositions of Mentha extracts (\% w/w).

\begin{tabular}{|c|c|c|c|c|c|}
\hline \multirow[b]{2}{*}{ Compounds } & \multicolumn{5}{|c|}{ Species } \\
\hline & $\begin{array}{c}\text { Mentha } \\
\text { spicata L. }\end{array}$ & $\begin{array}{l}\text { Mentha } x \\
\text { gentilis L. }\end{array}$ & $\begin{array}{l}\text { Mentha } \\
\text { crispa L. }\end{array}$ & $\begin{array}{c}\text { Mentha } \\
\text { piperita L. }\end{array}$ & $\begin{array}{l}\text { Mentha } x \\
\text { piperita L. }\end{array}$ \\
\hline a-Pinene & 1.03 & -- & 0.91 & 0.79 & 0.83 \\
\hline$\beta$-Pinene & 1.81 & -- & 1.08 & 1.18 & 1.25 \\
\hline Sabinene & 0.84 & -- & 0.57 & 0.75 & 0.61 \\
\hline Mircene & 1.86 & 1.24 & 1.60 & 0.68 & 0.32 \\
\hline Limonene & 3.18 & 0.70 & 20.61 & 3.81 & 2.55 \\
\hline 1,8 Cineol & 9.23 & 0.39 & 3.30 & 6.97 & 6.79 \\
\hline L- Mentone & 7.89 & -- & -- & 18.02 & 20.64 \\
\hline trans- Isopulegone & 0.86 & -- & -- & -- & -- \\
\hline cis- Isopulegone & 0.24 & -- & -- & -- & -- \\
\hline Pulegone & 55.49 & -- & -- & -- & -- \\
\hline Piperitone oxide & 4.48 & -- & -- & -- & -- \\
\hline cis-Ocimene & -- & 1.14 & 0.27 & 0.25 & 0.28 \\
\hline trans-Ocimene & -- & 0.62 & 0.10 & -- & -- \\
\hline Lynalol & -- & 31.19 & 0.43 & -- & -- \\
\hline Lynalil acetate & -- & 45.59 & -- & -- & -- \\
\hline$\beta$-Cariofilene & -- & 1.75 & 0.43 & 0.77 & 1.06 \\
\hline L- Menthol & -- & 0.60 & -- & 32.43 & 42.70 \\
\hline$\alpha$-Terpineol & -- & 4.21 & -- & -- & -- \\
\hline Neryl acetate & -- & 2.15 & -- & -- & -- \\
\hline Nerol & -- & 0.74 & -- & -- & -- \\
\hline Y- gurjunene & -- & 1.82 & -- & -- & -- \\
\hline Dihydrocarvone & -- & -- & 0.82 & -- & -- \\
\hline Dihydrocarvil acetate & -- & -- & 0.99 & -- & -- \\
\hline Dihydrocarveol & -- & -- & 1.68 & -- & -- \\
\hline $\mathrm{\gamma}$ - terpinene & -- & -- & -- & 0.44 & 0.23 \\
\hline Mentofurane & -- & -- & -- & 2.59 & 3.23 \\
\hline Menthyl acetate & -- & -- & 0.55 & 4.22 & 5.23 \\
\hline Neoisomenthol & -- & -- & -- & 6.12 & 5.01 \\
\hline Germacrene D & -- & -- & -- & 0.53 & 0.90 \\
\hline Carvone & -- & -- & 60.88 & 10.66 & -- \\
\hline
\end{tabular}

The potential value of the platinum electrode shifts to more positive values instantaneously with the Mentha extract addition. This is consistent with the chelation of Fe (II) species by the active chemical compounds present in the extract drop, linalyl acetate $(45.6 \%)$ and linalol (31.2\%). All other Mentha extracts were investigated by using the same procedure and showed similar behavior.

The difference among Mentha extracts regarding Fe (II) chelating ability was observed by comparing the potential displacement rate (Eq. 8). The changes in the linear potential after oil extract addition were used to plot DE vs. $t$, as shown in Figure 2 for Mentha x gentilis L. 


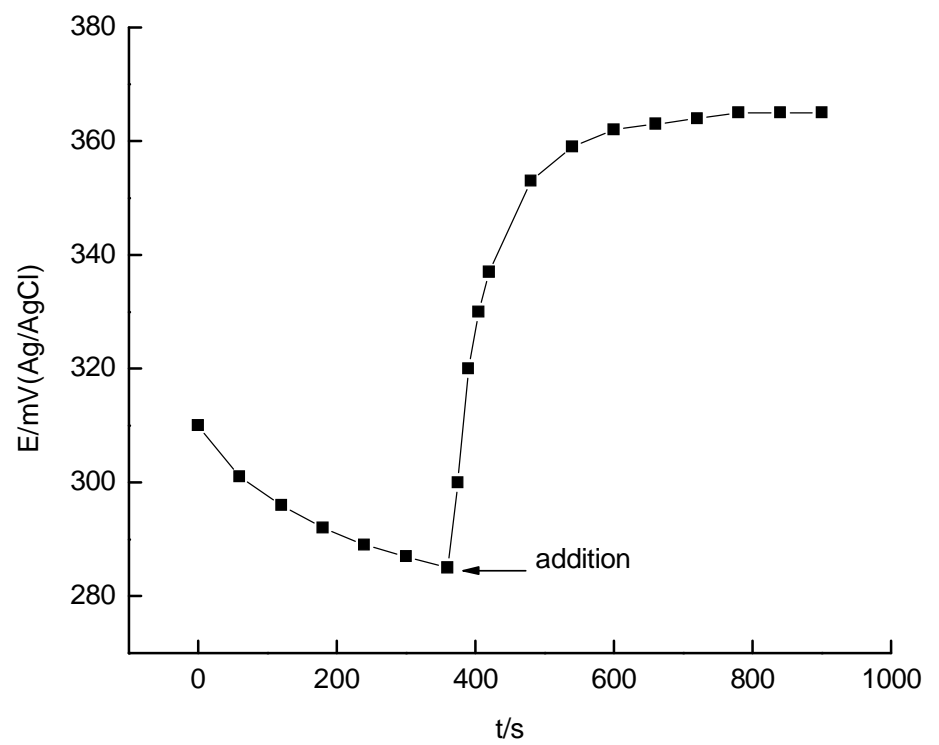

FIGURE 1. Open-circuit potential values of the platinum electrode after addition of Mentha $x$ gentilis $L$. extracts under constant stirring, at room temperature.

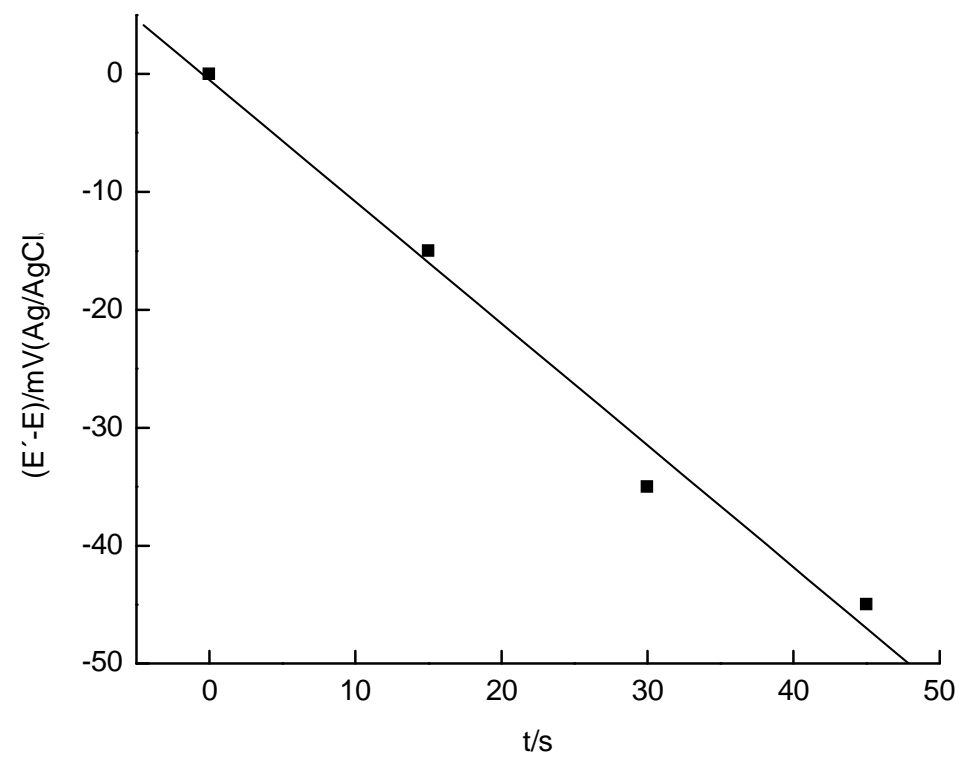

FIGURE 2. Plot of (DE) vs. time after Mentha $x$ gentilis L. extract addition.

This result confirms that chelation occurs through a first-order reaction regarding iron (II) concentration, as described above. The slope of this curve corresponds to the rate constant of the iron (II) chelation reaction. Table 3 presents the rate constants for all Mentha extracts, following the same procedure.

The ability to chelate iron (II) species is dependent on the chemical composition of each variety and was more effective with the extract of $M . x$ gentilis L., followed by M. piperita L. We are assuming that the ability to chelate iron (II) species is linked to the principal chemical compound present in each
TABLE 3. Rate constants of the iron (II) chelating reaction from other Mentha extracts.

\begin{tabular}{ll}
\hline \multicolumn{1}{c}{ Mentha species } & Rate constant $\left.\mathbf{k}^{-1} \mathbf{s}^{-1}\right)$ \\
\hline Mentha $\times$ gentilis $\mathrm{L}$ & $1.03 \pm 0.02$ \\
Mentha piperita $\mathrm{L}$ & $0.867 \pm 0.03$ \\
Mentha spicata $\mathrm{L}$ & $0.707 \pm 0.01$ \\
Mentha crispa $\mathrm{L}$ & $0.593 \pm 0.03$ \\
Mentha $x$ piperita $\mathrm{L}$ & $0.453 \pm 0.02$ \\
\hline
\end{tabular}


essential oil: $M$. spicata $L$. is rich in pulegone (55.49\%); M. x gentilis L. in linalyl acetate (45.59\%); M. crispa L. in carvone $(60.88 \%)$; M. piperita L. in Imenthol $(32.43 \%)$ and $M . x$ piperita L. in I-menthol $(42.70 \%)$.

\section{Cyclic Voltammetry}

These experiments were performed in order to characterize the interaction between the platinum electrode surface and the electroactive species present in Mentha extracts. However, to characterize the electrochemical behavior of the platinum electrode in this medium some experiments were carried out only with the supporting electrolyte under aerated and deaerated conditions, as shown in Figure 3.

This figure allowed the characterization of an important charge transfer process related to the electrochemical reduction of dissolved oxygen in ethanol. The current peak observed at $-1.2 \mathrm{~V}$ is related to this process.

The presence of M. spicata L. extract alters the current $x$ potential curve of the platinum electrode. Figure 4 shows the cyclic voltammograms recorded at $\mathrm{v}=50 \mathrm{mV} \mathrm{s}^{-1}$ during the cathodic potential sweep, in the absence and presence of two concentrations of M. spicata L. extracts.

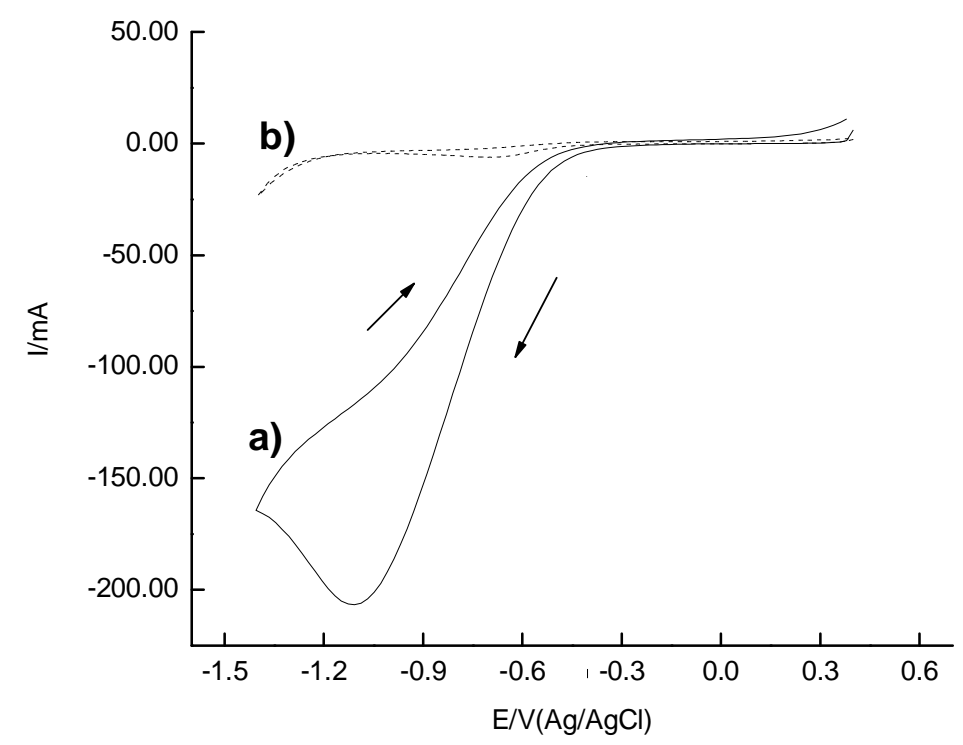

FIGURE 3. Cyclic voltammograms of the platinum electrode in ethanol with tetraethylammonium chloride $0.10 \mathrm{~mol} \mathrm{~L}^{-1}$, recorded at $\mathrm{V}=50 \mathrm{mV} \mathrm{s}^{-1}, \mathbf{a}$ ) with dissolved oxygen and $\mathbf{b}$ ) without dissolved oxygen.

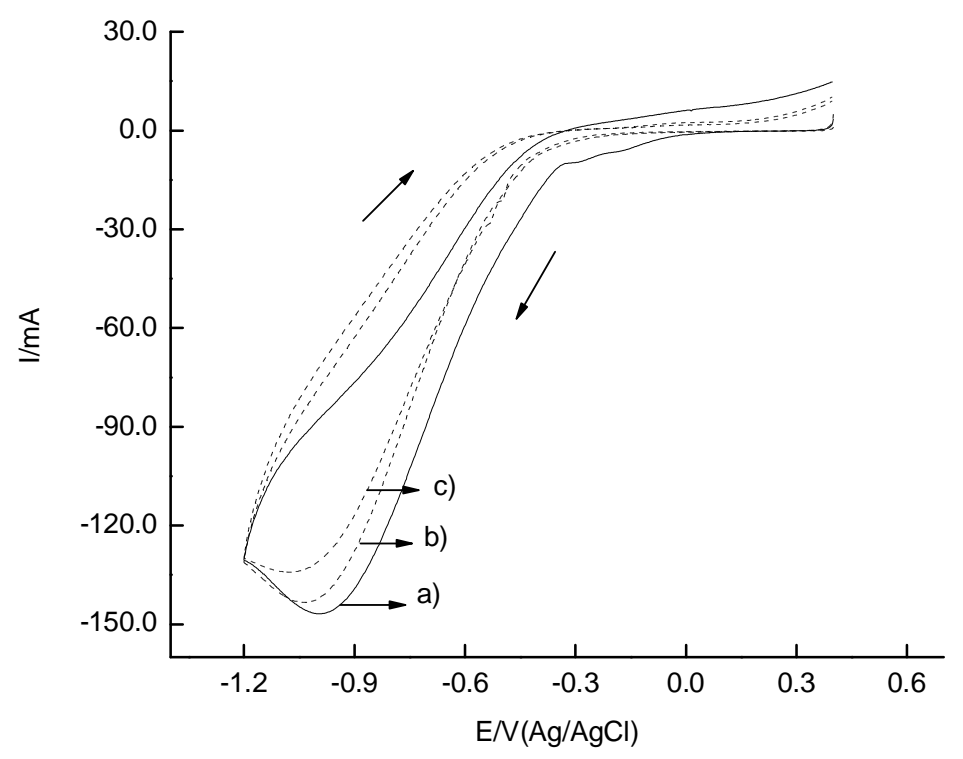

FIGURE 4. Cyclic voltammograms of the platinum electrode in aerated ethanol with tetraethylammonium chloride $0.10 \mathrm{~mol} \mathrm{~L}^{-1}$, recorded at $\mathrm{v}=50 \mathrm{mV} \mathrm{s}^{-1}, \mathrm{a}$ ) in the absence and $\mathrm{b}$ ) in the presence of Mentha spicata $\mathrm{L}$. extract 5.0 $\times 10^{-4} \mathrm{~g} \mathrm{~mL}^{-1}$ and c) $3.5 \times 10^{-3} \mathrm{~g} \mathrm{~mL}^{-1}$. 
The presence of one drop of $M$. spicata $L$. $\left(5.0 \times 10^{-4} \mathrm{~g} \mathrm{~mL}^{-1}\right)$ reduces the current values, suggesting the inhibition of the charge transfer process due to the oxygen electroreduction. The second addition (curve $\mathrm{c}$ ) verified this effect. The main conclusion drawn from this figure is that the antioxidant capacity of M. spicata L. essential oil was also observed by cyclic voltammetry.

However, the experiments repeated with $M$. piperita L. extract showed an unexpected electrochemical behavior, as shown in Figure 5.

In this case, instead of a cathodic current decrease, a visible cathodic peak appears after the addition of $M$. piperita L. essential oil, which enhances with extract concentration increase. This current peak is probably related to the electroreduction of the electroactive species present in the essential oil. Similar results were observed with the other Mentha extracts, suggesting that the active compounds present in Mentha essential oils interact with the platinum electrode surface.

Despite this result, it seems reasonable to infer that the oxygen electroreduction is still occurring on the electrode surface at the corresponding peak potential. The current value at this potential for this process decreases in the presence of Mentha extract. This effect may be associated with the oxygen concentration decrease near the electrode surface.

\section{Antioxidant capacity}

These experiments were planned based on the ability of the active compounds of Mentha extracts to react with dissolved oxygen. This reaction decreases the oxygen concentration near the electrode surface, as detected by differential pulse voltammetry (Korotkova et al., 2002). The mathematical base of this method is well described in literature (Tur'yan et al., 2004; Korotkova et al., 2005).

Prior to the addition of Mentha extract, some experiments were carried out in order to verify the electrochemical behavior of the platinum electrode in aerated and deaerated supporting electrolyte, as shown in Figure 6.

The comparison of these curves suggests that the current peak observed at around $-1.20 \mathrm{~V}$ is related to the dissolved oxygen electroreduction since in the absence of oxygen (curve b) the charge transfer process was not observed.

The presence of a small amount of $M$. spicata L. extract in the medium changes the voltammogram of the platinum electrode as shown in Figure 7.

Initially the voltammogram of the oxygen reduction (curve a) was obtained in order to determine the limiting value of the oxygen electroreduction current at around $-1.2 \mathrm{~V}$. The antioxidant extract was added and after 10 minutes of stirring a new voltammogram was recorded (curve b). A visible charge transfer process was observed at $-0.50 \mathrm{~V}$, probably involving the electrochemical reduction of the active compounds of M. spicata L. extract, followed by a current value decrease associated with the oxygen electroreduction.

Applying the same procedure recommended in literature (Korotkova et al., 2002; Korotkova et al., 2005) the antioxidant capacity was determined at different concentrations of $M$. spicata L. extracts. The limiting current of the oxygen electroreduction against antioxidant concentration is shown in Figure 8.

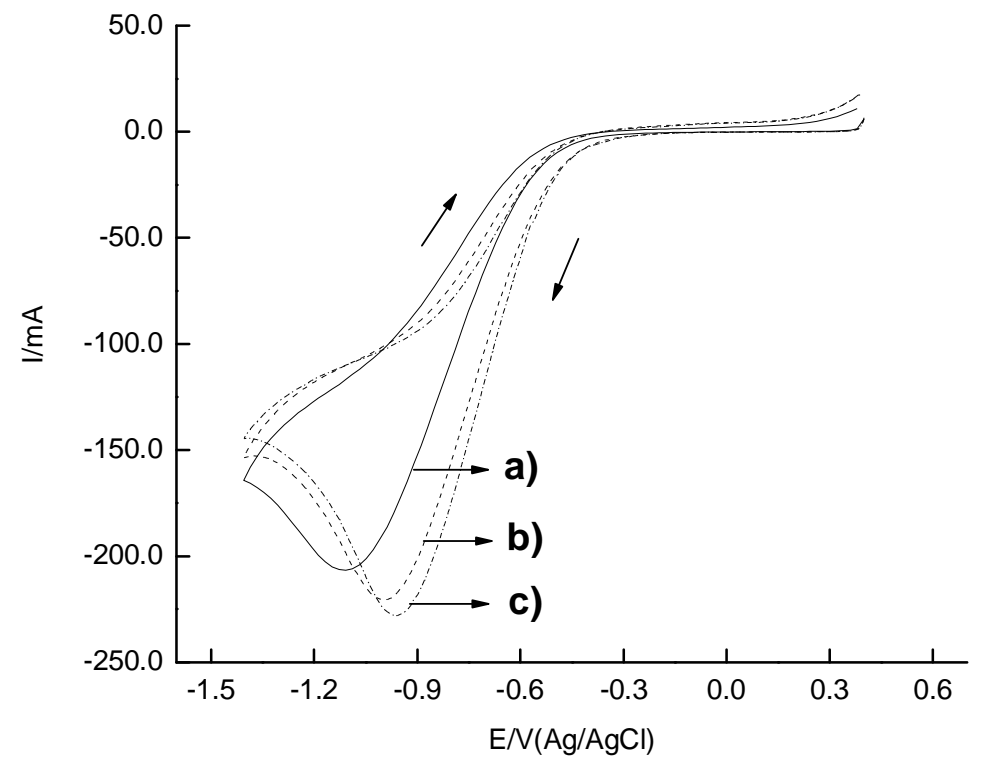

FIGURE 5. Cyclic voltammograms of the platinum electrode in ethanol with $0.10 \mathrm{~mol} \mathrm{~L}^{-1}$ of tetraethylammonium chloride, recorded at $50 \mathrm{mV} \mathrm{s}^{-1}$, a) in the absence and b) in the presence of Mentha spicata L. extract $5.0 \times 10^{-4} \mathrm{~g} \mathrm{~mL}^{-1}$ and c) $3.5 \times 10^{-3} \mathrm{~g} \mathrm{~mL}^{-1}$. 


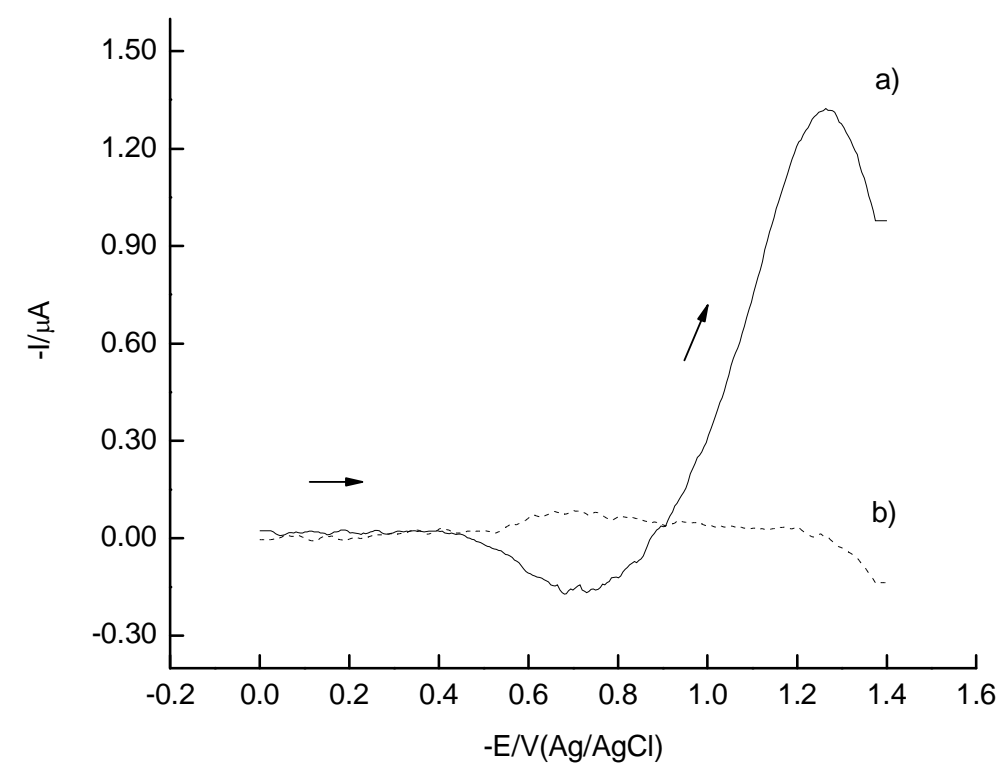

FIGURE 6. Differential pulse voltammograms of the platinum electrode in a) aerated and b) deaerated ethanol with tetraethylammonium chloride $0.10 \mathrm{~mol} \mathrm{~L}^{-1}$, recorded at $\mathrm{v}=50 \mathrm{mV} \mathrm{s}^{-1}$.

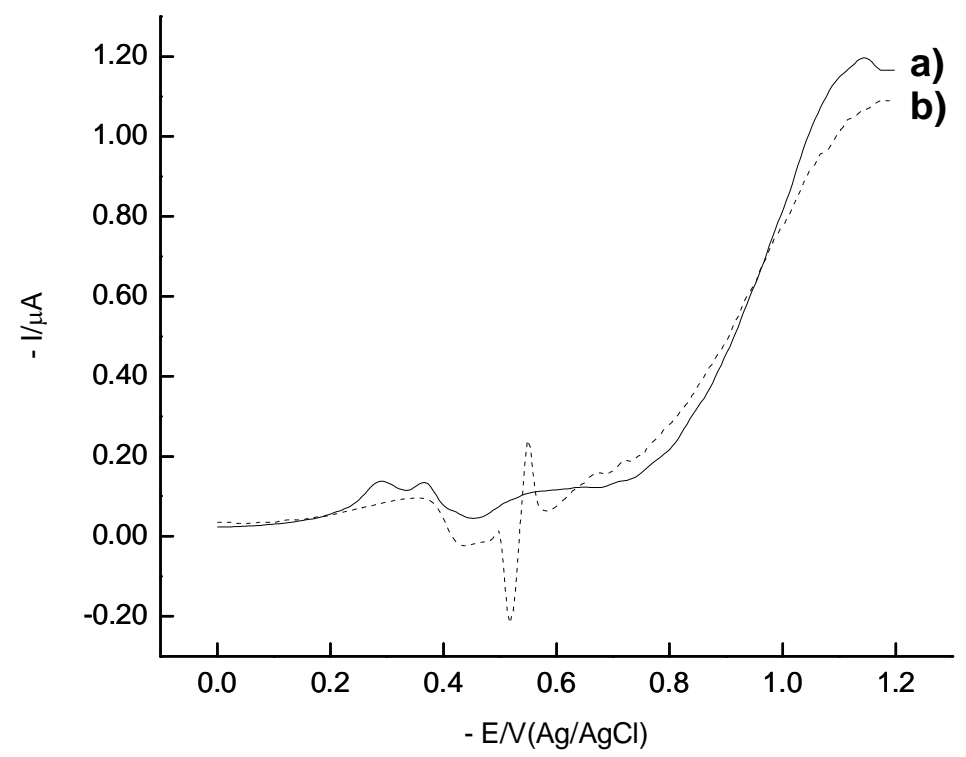

FIGURE 7. Differential pulse voltammograms of the platinum electrode in ethanol with tetraethylammonium chloride $0.10 \mathrm{~mol} \mathrm{~L}^{-1}$, recorded at $\left.\mathrm{V}=50 \mathrm{mV} \mathrm{s}^{-1}, \mathbf{a}\right)$ in the absence and $\mathbf{b}$ ) in the presence of Mentha spicata L. extract $3.5 \mathrm{x}$ $10^{-3} \mathrm{~g} \mathrm{~mL}^{-1}$.

As observed in the figure, a straight line was obtained in the range of the antioxidant concentration. The tangent of the slope coefficient of this line appears to be a coefficient of the antioxidant capacity $(\mathrm{K})$ represented by the equation:

$$
\mathrm{K}=\frac{\Delta \mathrm{I}}{\left(\mathrm{I}_{\text {ox }}-\mathrm{I}_{\mathrm{res}}\right) \Delta \mathrm{C}}
$$

where $D C$ is the change in the antioxidant concentration in $\mathrm{mL}^{-1}$; $\mathrm{Dl}$ is the change in the oxygen reduction current; $I_{\text {ox }}$ is the limiting current of the oxygen reduction without antioxidant in the solution and $I_{\text {res }}$ is the residual current density without oxygen in the solution, which was observed to be close to zero (see Figure 6). The value found for M. spicata $\mathrm{L}$. was $\mathrm{K}=76.5 \mathrm{~mL} \mathrm{~g}^{-1}$. This value is consistent with that observed for other plant extracts (Korotkova et al., 2003).

However, an unexpected result was obtained when the same experiment was repeated with $M$. piperita L., as shown in Figure 9. 


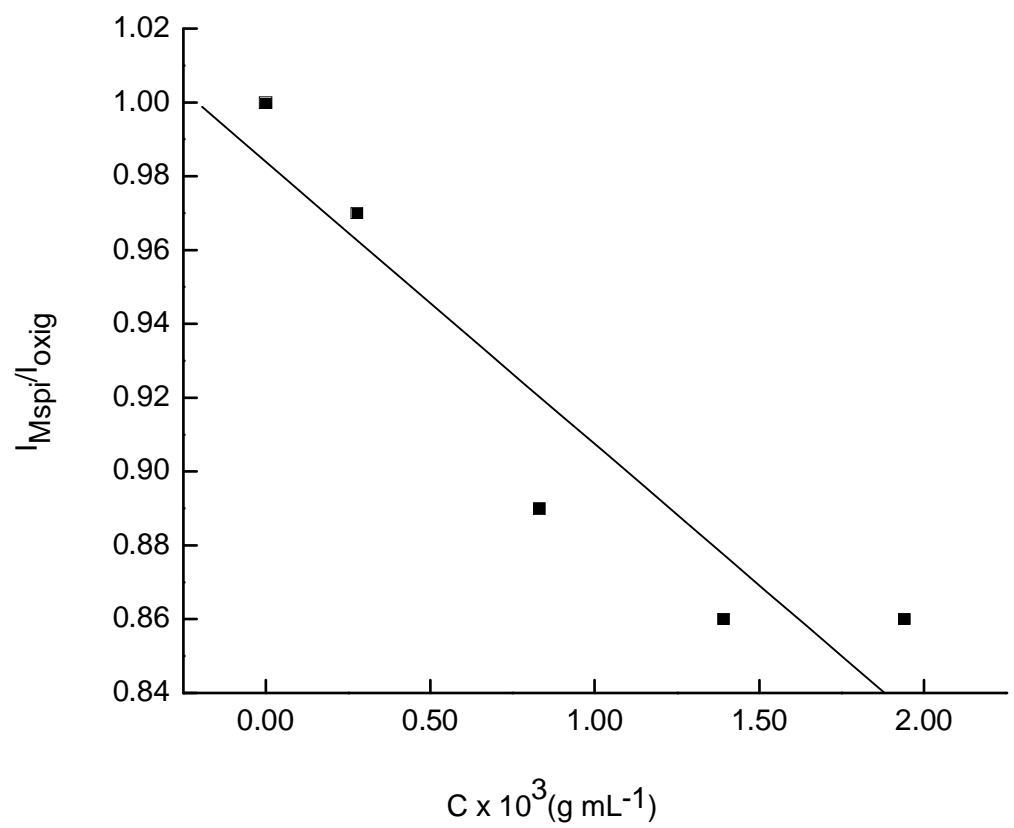

FIGURE 8. Relative change in the oxygen reduction current density against Mentha spicata L. concentration in ethanolic solution.

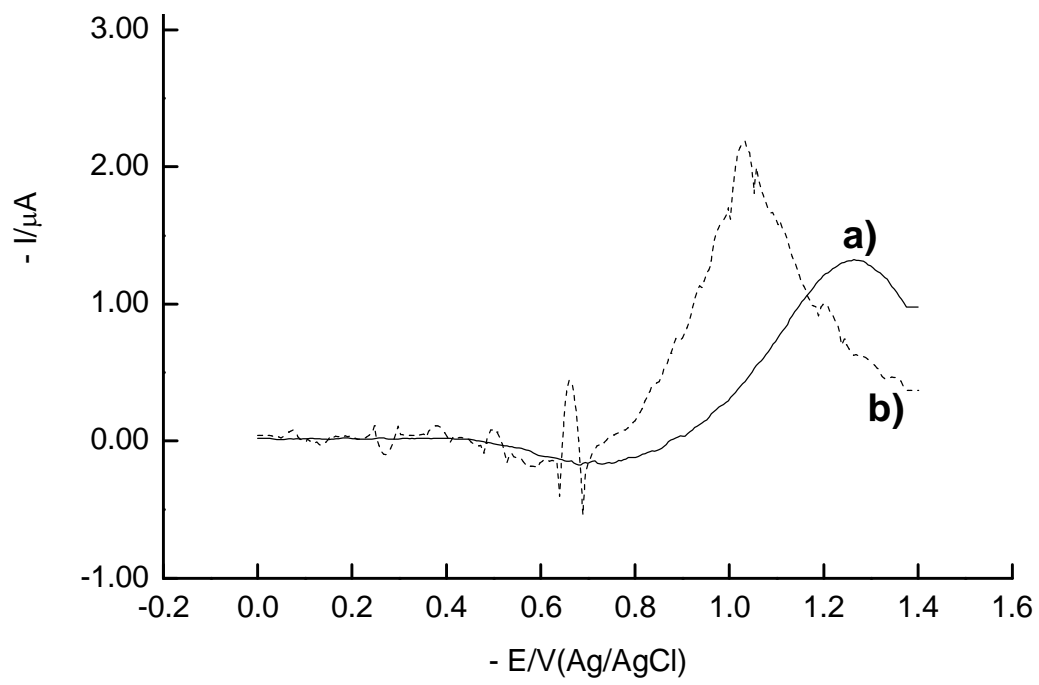

FIGURE 9. Differential pulse voltammograms of the platinum electrode in ethanol with tetraethylammonium chloride $0.10 \mathrm{~mol} \mathrm{~L}^{-1}$, recorded at $\left.\mathrm{v}=50 \mathrm{mV} \mathrm{s}^{-1}, \mathbf{a}\right)$ in the absence and $\mathbf{b}$ ) in the presence of Mentha spicata L. extract 3.5 $\times 10^{-3} \mathrm{~g} \mathrm{~mL}^{-1}$.

The electrochemical behavior of the electrode in the presence of Mentha extract was characterized by a current peak at around $-1.0 \mathrm{~V}$, probably related to the electroreduction of some active compounds in the extract. Despite this result, it seems reasonable to infer that the oxygen electroreduction is still occurring on the electrode surface at the corresponding peak potential $(-1.2 \mathrm{~V})$. The current value at this potential for the process decreases in the presence of Mentha extract. Based on this effect the limiting current of the oxygen electroreduction against antioxidant concentration was calculated and the result is shown in Figure 10.

The same straight profile was observed, allowing the calculation of the coefficient of antioxidant capacity $(K)$ from the tangent of the slope angle of this line. The value found for $M$. piperita $L$. was $K=$ $122.4 \mathrm{~mL} \mathrm{~g}^{-1}$. Using the same procedure, all antioxidant capacity coefficients for other Mentha species were determined, as shown in Table 4.

The comparison of the values found by using this method suggests that all Mentha species have some kind of antioxidant capacity. However, $M . x$ gentilis L. variety showed a notable ability compared 


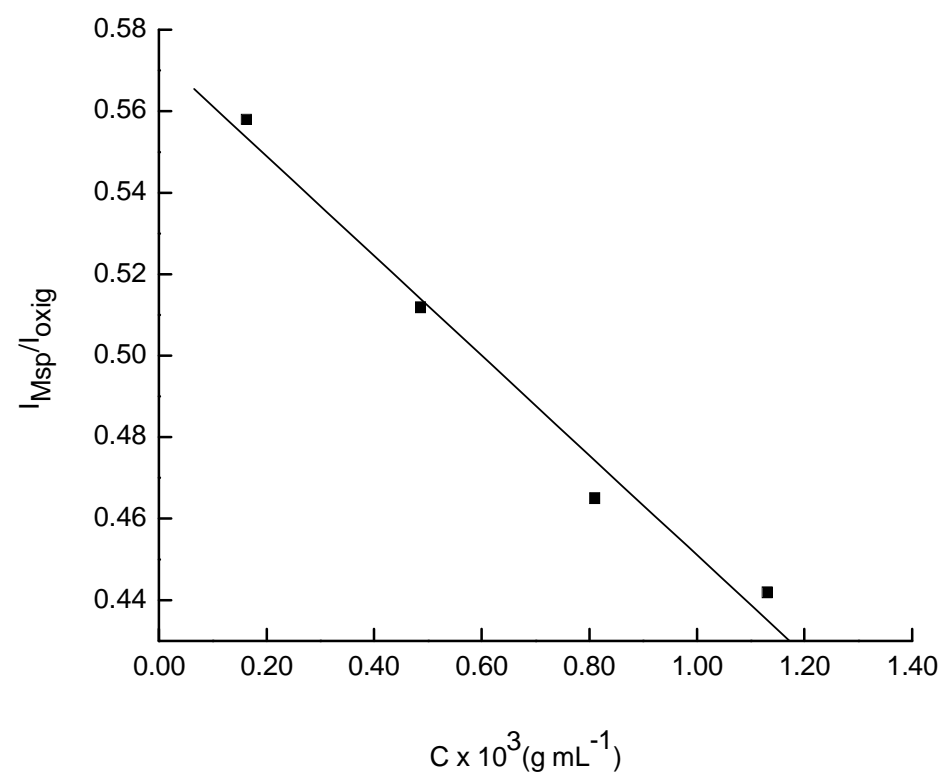

FIGURE 10. Relative change in the oxygen reduction current density against Mentha piperita L. concentration in ethanolic solution.

TABLE 4. Coefficient of antioxidant capacity for other Mentha extracts.

\begin{tabular}{lr}
\hline Mentha varieties & $\begin{array}{r}\text { Rate constant K } \\
\left(\mathbf{m L ~ g}^{-1}\right)\end{array}$ \\
\hline Mentha x gentilis L. & $270.1 \pm 0.9$ \\
Mentha piperita L. & $122.4 \pm 0.2$ \\
Mentha spicata L. & $76.5 \pm 0.4$ \\
Mentha crispa L. & $41.4 \pm 0.5$ \\
Mentha x piperita L. & $155.9 \pm 0.7$ \\
\hline
\end{tabular}

with the other varieties. This result was in agreement with the differentiated ability of this variety to chelate iron (II) compared with the other Mentha species. Here it is also reasonable to assume that the antioxidant capacity is linked to the principal chemical compound present in each essential oil: $M$. spicata L. is rich in pulegone $(55.49 \%) ; M . x$ gentilis L. in linalyl acetate (45.59\%); M. crispa L. in carvone (60.88\%); M. piperita $\mathrm{L}$. in $\mathrm{L}-\mathrm{menthol}(32.43 \%)$ and $M$. $x$ piperita $\mathrm{L}$. in Lmenthol (42.70\%).

\section{CONCLUSION}

The antioxidant capacity of five Mentha species was determined by using differential pulse voltammetry. The reduction in the limiting current value of the oxygen electroreduction in ethanol was used to calculate the antioxidant capacity $(\mathrm{K})$ of these species. The essential oil extract of Mentha $x$ gentilis $\mathrm{L}$. had a higher $\mathrm{K}$ value than those of the other species.
Cyclic voltammetry experiments verified the interaction between the electrode surface and the active compounds present in the essential oils. A new methodology to determine $\mathrm{Fe}$ (II) chelation ability of active compounds is proposed. There was a well defined linear relationship among the open circuit potential variations against time. This effect suggests a first-order chemical reaction between $\mathrm{Fe}(\mathrm{II})$ and the active compounds in the oil extract.

The rate constants of the iron (II) chelation reaction were different for each extract. However, $M$. $x$ gentilis $\mathrm{L}$. extract showed the highest rate constant compared with the other extracts.

\section{REFERENCE}

ARABSHAHI-D, D.S.; DEVI, D.V.; UROOJ, A. Evaluation of antioxidant activity of some plant extracts and their heat, pH and storage stability. Food Chemistry, v.100, p.11005, 2007.

CAPECKA, E.; MARECZEK, A.; LEJA, M. Antioxidant activity of fresh and dry herbs of some Laminaceae species. Food Chemistry, v.93, p.223-6, 2005.

CHANWITHEESUK, A.; TEERAWUTGULRAG, A.; RAKARIYATHAM, N. Screening of antioxidant activity and antioxidant compounds of some edible plants of Thailand. Food Chemistry, v.92, p.491-7, 2005.

CHOUDHURY, R.P.; KUMAR, A.; GARG, A.N. Analysis of Indian (Mentha spicata) for essential, trace and toxic elements and its antioxidant behaviour. Journal Pharmaceutical and Biomedical Analysis, v.41, p.82532, 2006.

DORMAN, H.J.D. et al. Antioxidant properties and composition of aqueous extracts from Mentha species, hybrids, varieties and cultivars. Journal of Agricultural and Food Chemistry, v.51, p.4563-9, 2003. 
DUKIC, N.M. et al. Antimicrobial and antioxidant activities of three Mentha species essential oils. Plant Medicinal, v.69, p.413-9, 2003.

FERREIRA, A. et al. The in vitro screening for acetylcholinesterase inhibition and antioxidant activity of medicinal plants from Portugal. Journal of Ethnopharmacology, v.108, p.31-7, 2006.

GULLUCE, M. et al. Antimicrobial and antioxidant properties of the essential oils and methanol extract from Mentha longifolia L. ssp. Iongifolia. Food Chemistry, v.103, p.1449-56, 2007.

KANATT, S.R.; CHANDER, R.; SHARMA, A. Antioxidant potential of mint (Mentha spicata L.) in radiationprocessed lamb meat. Food Chemistry, v.100, p.451-8, 2007.

KOROTKOVA, E.I.; KARBAINOV, Y.A.; SHEVCHUK, A.V. Study of antioxidant properties by voltammetry. Journal of Electroanalytical Chemistry, v. 518, p.56-60, 2002. KOROTKOVA, E.I.; KARBAINOV, Y. A.;AVRAMCHIK, O.A. Investigation of antioxidant and catalytic properties of some biologically active substances by voltammetry. Analytical and Bioanalytical Chemistry, v.375, p.465-8, 2003.

KOROTKOVA, E.I. et al. Investigation of antioxidant activity and lipophilicity parameters of some preservatives. Electrochimica Acta, v.51, p.324-32, 2005.
KOSAR, M.; DORMAN, H.J.D.; HILTUNEN, R. Effect of and acid treatment on the phytochemical and antioxidant characteristics of extracts from selected Laminaceae al species. Food Chemistry, v.91, n.3, p.525-33, 2005.

MARINOVA, E.M.; YANISHLIEVA, N.V. Antioxidative activity of extracts from selected species of the family Laminaceae in sunflower oil. Food Chemistry, v.58, n.3, p.245-8, 1997.

MATA, A.T. et al. Antioxidant and antiacetylcholinesterase activities of five plants used as Portuguese food spices. Food Chemistry, v.103, p.778-86, 2007.

POLITEO, O.; JUKIC, M.; MILOS, M. Chemical composition and antioxidant activity of essential oils of twelve spice plants. Croatica Chemica Acta, v.79, n.4, p.545-52, 2006. TUR'YAN, Y.I.; GORENBEIN, P.; KOHEN. R. Theory of the oxygen voltammetric electroreduction process in the presence of an antioxidant for estimation of antioxidant activity. Journal of Electroanalytical Chemistry, v.571, p.183-8, 2004.

YADEGARINIA, D. et al. Biochemical activities of Iranian Mentha piperita L. \& Myrtus communis L. essential oil. Phytochemistry, v.67, p.1249-55, 2006.

YAMAUCHI, R. et al. Effect of metal salts and fructose on the autoxidation of methyl linoleate in emulsions. Agricultural Biology Chemistry, v.52, n.3, p.849-50, 1988. 